\title{
Behavior of horses kept in different types of stalls in the semiarid region of Minas Gerais, Brazil
}

\author{
Maria Dulcinéia da Costa ${ }^{a}$ (D) Cinara da Cunha Siqueira Carvalho ${ }^{(i D} \mid$ Wemerson Fábio Gomes \\ Ribas $^{\text {(D) }}$ | Virgílio Mesquita Gomes ${ }^{\text {(D) }}$ | Alvimara Felix dos Reis ${ }^{b}$ | Sara Guedes de Paula ${ }^{(i D}$ | \\ Vicente Ribeiro Rocha Junior ${ }^{2}$ | Ricardo Rodielle Rodrigues Gomes ${ }^{(i D}$ | Flávio Pinto Monção
}

Universidade Estadual de Montes Claros, Departamento de Ciências Agrárias, Janaúba, MG, Brasil.

bUniversidade Federal de Viçosa, Departamento de Zootecnia, Viçosa, MG, Brasil.

'Médico Veterinário Autônomo.

Corresponding author: dulcineia.costa@unimontes.br

\begin{abstract}
The objective of this study was to evaluate the feeding and agonistic behavior of Quarter Horses kept in different types of stalls in the semiarid region of Minas Gerais. A completely randomized design with two treatments (two types of stalls) and seven replicates (seven days of evaluation) was used. Four Quarter Horse mares and four stallions were used per treatment. Behavioral observations were made at 10 -minute intervals for 24 hours. The stall environment was characterized by the following variables: air temperature, relative humidity, and black globe temperature for subsequent estimation of the wet-bulb globe temperature. Feeding behavior variables included: time spent eating concentrate and time spent eating roughage (hours), bite rate (bites/min), and the number of daily bites (bites/day). Zinc-roofed stalls had higher air temperatures than clay-roofed stalls and the external environment, averaging $28.2,27.0$, and 27.4 oC, respectively, while relative humidity was significantly lower in the external environment (65.80\%). Horses housed in zinc-roofed stalls had longer feeding times $(8.32 \mathrm{~h}$ ) than animals kept in clay-roofed stalls ( $7.22 \mathrm{~h}$ ). Approximately $94 \%$ of the total feeding time was spent eating roughage and $73 \%$ of the time was spent resting and walking, regardless of the covering type. Although environmental variables showed thermal discomfort, the roofing material did not alter the feeding behavior of stabled horses in the semiarid region of Minas Gerais, suggesting an adaptation to the studied conditions. The feeding frequency should be increased to avoid a long resting time.
\end{abstract}

Keywords behavior, farm buildings, horses, stereotypies

\section{Introduction}

When horses are stabled, humans become responsible for the supply of food, which is usually rich in readily fermentable carbohydrates (Rezende et al 2006a). The association between diet and stall confinement may lead to altered behavioral responses, called stereotypies (Mills 2005). According to Canal Junior (2015), horses confined for extended periods exhibit more abnormal behavior than freegrazing animals. Thus, increasing fiber intake may be an alternative to reduce these abnormal behaviors in stabled horses (Thorne et al 2005; Brandi and Furtado 2009).

The choice of roofing material and type are of paramount importance in providing thermal comfort to horses, especially in areas where the average air temperature throughout the year is high, and the relative humidity is low. Several roofing materials are available in the market, although the most used are clay and zinc tiles. Zinc roofing is inexpensive to purchase and install but has a high ability to absorb sunlight as heat, making the environment uncomfortable for animals. Clay-roofed stalls are more expensive but more efficient in thermal insulation, creating an improved microclimate within the stable. Moreover, the area of the stall should allow animals to walk comfortably.
Additionally, the ceiling height should have at least $2.80 \mathrm{~m}$ height to reduce the radiant heat load and can be combined with windows for natural ventilation, promoting thermal comfort (Baêta and Souza 2010).

Studies that consider the effect of stall architecture on behavioral responses in horses are still scarce in the literature. In parallel, horse breeders demand alternatives that promote thermal comfort and favor horse performance and profitability.

The objective of this study was to evaluate the feeding and agonistic behavior of horses kept in stalls with different roof coverings in the semiarid region of Minas Gerais.

\section{Materials and Methods}

Animal care and handling procedures followed the guidelines of the Ethics Committee on the Use of Animals in Experiments (CEEBEA; protocol $\mathrm{N}^{\circ} 141 / 2017$ ).

The experiment was carried out in a private farm in the municipality of Janauba (15047'50"S and 4318'31"W; altitude of $516 \mathrm{~m}$ ), located in the state of Minas Gerais, Brazil. The climate in the region is Aw - tropical savanna, according to the Köppen-Geiger's classification system, characterized by long drought periods (Antunes 1994), with a maximum and minimum air temperatures of $27 \stackrel{\circ}{\circ}$ and $24.2 \stackrel{\circ}{\circ}$, 
respectively, and an average relative humidity $(\mathrm{RH})$ of $39 \%$ (INMET 2017).

A completely randomized design with two treatments (stalls with two types of roof covering - clay and zinc) and seven replicates (seven days of evaluation) was used. The stalls were characterized according to their building structure. Clay-roofed stalls were built with masonry walls provided with natural ventilation, wooden roof framing and clay tiles, dimensions of $4 \times 3 \mathrm{~m}$, ceiling height of $2.0 \mathrm{~m}$, and two-leaf wooden doors to allow viewing the horses from the outside. Zinc-roofed stalls were built with masonry walls provided with natural ventilation, iron roof framing and zinc roof sheets, dimensions of $3.8 \mathrm{~m} \times 3.8 \mathrm{~m}$, ceiling height of $3.0 \mathrm{~m}$, and iron bar windows for outside view but not allowing horses to put their head out of the stall.

A total of eight Quarter Horse animals were divided into two groups of four horses (two mares and two stallions per treatment) kept in individual stalls. The horses had a mean age of 5.0 years and a mean body weight (BW) of 477 $\mathrm{kg}$. A total of $5 \mathrm{~kg}$ of roughage (Cynodon spp.) was supplied to each animal twice a day at 7 a.m. and 7 p.m. The concentrate was offered at 8 a.m. and 8 p.m. at a rate of 2.0 kg per animal.

Samples of the feed supplied were weighed, identified, packed in plastic bags, and oven-dried in a forcedair oven at 55 oC for 72 hours. After drying, the samples were ground in a Wiley mill to pass a 1-mm screen and oven-dried at $105 \stackrel{\circ}{\circ}$ for $24 \mathrm{~h}$. The chemical composition (Table 1 ) was determined at the Laboratory of Food Analysis by analyzing the dry matter (DM), crude protein (CP), neutral detergent fiber (NDF), acid detergent fiber (ADF), and lignin (LIG) contents according to the procedures described by Detmann et al. (2012).

The stall environment was characterized by the following variables: air temperature, relative humidity, dew point temperature, and black globe temperature, obtained using RHT10 dataloggers set to collect information every 30 minutes. A set of dataloggers was fixed in a representative stall and outside of the stable. Then, it was possible to estimate the wet-bulb globe temperature (WBGT) as proposed by Buffington et al (1981):
WBGT $=\mathrm{DPT}+0.36 \times \mathrm{BGT}+41.5$

where DPT = dew point temperature $\left({ }^{\circ} \mathrm{C}\right) ; \mathrm{BGT}=$ black globe temperature $\left({ }^{\circ} \mathrm{C}\right)$.

Feeding behavior was assessed visually at 10-minute intervals. The total daily time was calculated as the sum of the total amount of time animals spent on each activity (Hodgson 1985). The horses were observed for 24 uninterrupted hours divided into four periods: the morning period ( 6 a.m. to 12 p.m.), the afternoon (12:10 p.m. to 6 p.m.), the evening (6:10 p.m. and 12 a.m.), and dawn (12:10 a.m. to 6 a.m.).

The time spent eating roughage was based on the bite rate, calculated according to the number of bites per day. In contrast, the time spent eating concentrate was measured directly. The bite rate was obtained with the aid of a chronometer by counting the number of bites in one minute. The given bite rate represents the mean observed for 30 minutes during the morning feeding (from 8 a.m. to 10 a.m.). Six observations of each animal were done during these 30 minutes of evaluation, totaling 30 observations per treatment, according to the adapted methodology of Santos et al (2006). The number of bites per day was calculated by the product between the mean bite rate and the mean time spent eating roughage per day, in minutes.

The time spent resting was divided into several behavioral activities: defecation or urination; resting position (standing up or lying down); any movement; sleeping position (standing up, lying down or just drowsy); behavioral disorders such as wood-chewing, cribbing, and licking the feed trough.

Forty liters of water at room temperature were supplied per stall per day at 7 a.m. and 7 p.m. around noon. Water volume was measured again, and refusals were taken to estimate intake, calculated as offered minus refused.

The F-test was used to compare means of variables related to intake, while the means of climatic variables were compared by the Scott-Knott's and Tukey's test at a confidence level of $5 \%$. The mathematical model used was:

$\hat{\mathrm{Y}}_{i j}=\mu+$ stalls $_{\mathrm{i}}+\mathrm{e}_{i j}$

where $\mathrm{Y}=$ Dependent Variables; $\mu=$ Overall Average; Stalls $_{i}=$ stall cover effect ( $i=$ ceramic, zinc); $e_{i j}=$ experimental error associated with all observations.

Table 1 Means of chemical composition of feed ingredients consumed by stabled horses in different types of stalls.

\begin{tabular}{|c|c|c|c|c|}
\hline \multirow{2}{*}{ Chemical composition } & \multicolumn{2}{|c|}{ Clay-roofed stalls } & \multicolumn{2}{|c|}{ Zinc-roofed stalls } \\
\hline & Hay & Concentrate & Hay & Concentrate \\
\hline Dry matter (\%) & 90.51 & 90.39 & 90.51 & 90.26 \\
\hline Crude protein (\%) & 9.85 & 16.98 & 9.85 & 13.96 \\
\hline Ash (\%) & 5.20 & 5.68 & 5.20 & 5.70 \\
\hline Ether extract (\%) & 3.55 & 4.24 & 3.55 & 4.27 \\
\hline $\operatorname{NDF}^{1}(\%)$ & 78.53 & 63.61 & 78.53 & 62.52 \\
\hline $\mathrm{ADF}^{2}(\%)$ & 34.89 & 12.80 & 34.89 & 12.75 \\
\hline Lignin (\%) & 3.60 & 1.38 & 3.60 & 1.25 \\
\hline
\end{tabular}

${ }^{1} \mathrm{NDF}=$ neutral detergent fiber; ${ }^{2} \mathrm{ADF}=$ acid detergent fiber. 


\section{Results}

The mean air temperature and relative humidity in the stalls and the external environment were significantly different $(P<0.05)$ throughout the experiment (Table 2). The air temperature was significant different between stalls $(P<$ $0.05)$, although the air temperature in clay-roofed stalls was similar to the observed in the external environment. Although similar for both roofing materials, the relative humidity was lower inside the stalls compared to the external environment. The heat was dissipated more easily in clayroofed stalls $\left(27.0^{\circ} \mathrm{C}\right)$ than in zinc-roofed stalls $\left(28.2^{\circ} \mathrm{C}\right)$. Zincroofed stalls are $3.0 \mathrm{~m}$ high, while clay-roofed stalls have a ceiling height of $2.0 \mathrm{~m}$.

The covering type did not influence the time spent eating concentrate (Table $3 ; P>0.05$ ). On the other hand, the time spent eating roughage was higher $(P<0.05)$ in horses kept in the zinc-roofed stalls. There was no difference in bite rate between groups, but the number of bites was higher in animals housed in zinc-roofed stalls.

The crude protein and digestible energy requirements were met when considering horses in light work with a mean body weight of $500 \mathrm{~kg}$. There was no difference $(P>0.05)$ in water intake between horses kept in clay- and zinc-roofed stalls (Table 4).

Horses kept in zinc-roofed stalls spent more time feeding than those in clay-roofed stalls (Table 5). Approximately $94 \%$ of the total feeding time was spent eating roughage and $73 \%$ of the time was spent resting and walking, regardless of the covering type. Horses kept in zinc-roofed stalls spent more time sleeping, cribbing, restless, licking, and wood-chewing than animals kept in clay-roofed stalls (Table $5)$. Horses kept in clay-roofed stalls spent less time walking (1.25\%) and spent a long time lying down and sleeping (3.25 and $12.82 \%$, respectively).

Table 2 Means of climate variables according to stall roof covering.

\begin{tabular}{lcccc}
\hline Climate variables & Clay-roofed stalls & Zinc-roofed stalls & External environment & $\mathrm{CV}(\%)^{1}$ \\
\hline Air temperature $\left({ }^{\circ} \mathrm{C}\right)$ & $27.0^{\mathrm{b}}$ & $28.2^{\mathrm{a}}$ & $27.4^{\mathrm{b}}$ & 5.7 \\
Relative humidity (\%) & $69.4^{\mathrm{a}}$ & $68.1^{\mathrm{a}}$ & $65.8^{\mathrm{b}}$ & 6.7 \\
WBGT $^{2}$ & $76.0^{\mathrm{a}}$ & $77.1^{\mathrm{a}}$ & $76.7^{\mathrm{a}}$ & 3.1 \\
\hline
\end{tabular}

Means followed by different letters in the row differ by Scott-Knott's test $(P<0.05)$.

${ }^{1} \mathrm{CV}$ - Coefficient of variation.

${ }^{2}$ WBGT = wet-bulb globe temperature.

Table 3 Means of time spent eating concentrate and roughage, bite rate and number of bites per day in horses according to stall roof covering.

\begin{tabular}{lcc}
\hline Variables & Clay-roofed stalls & Zinc-roofed stalls \\
\hline Time spent eating concentrate (min) & $40.0^{\mathrm{A}}$ & $45.0^{\mathrm{A}}$ \\
Time spent eating roughage (hours) & $6.82^{\mathrm{B}}$ & $7.87^{\mathrm{A}}$ \\
Bite rate (bites/min) & $8.27^{\mathrm{A}}$ & $8.56 \mathrm{~A}$ \\
Number of bites (bites/day) & $3377.4^{\mathrm{B}}$ & $4152.7^{\mathrm{A}}$
\end{tabular}

Means followed by different letters in the row differ by the F-test $(P<0.05)$.

Table 4 Nutritional requirements and nutrient supplied to horses kept in different types of stalls.

\begin{tabular}{lccccc}
\hline \multirow{2}{*}{ Variables } & \multicolumn{3}{c}{ NRC 2007} & \multicolumn{2}{c}{ Consumed } \\
\cline { 2 - 6 } & Maintenance & Light work & Total & Clay-roofed stalls & Zinc-roofed stalls \\
\hline Crude protein (g) & 630 & 699 & 1329 & 1505 & 1481 \\
Energy (Mcal) & 16.2 & 20 & 36.2 & 39.25 & 39.19 \\
Water (Liters) & 2L/kg.DM' & 2L/kg.DM & 27 & 17.82 & 16.61 \\
\hline
\end{tabular}

'DM- dry matter

\section{Discussion}

All solar radiation energy incident on zinc is absorbed and rapidly conducted due to its low thermal insulation properties. Clay tiles absorb energy from solar radiation and dampen it in the thicker material of distinct chemical composition, reducing the heat absorbed by the roof and allowing slow release of the remaining heat load throughout the day. According to Morgan (1996), the comfort zone for horses depends on their ability to maintain an adequate thermal balance and their mechanisms of physiological regulation in a given environment. The thermoneutral zone for the horses ranges from 5 to $25{ }^{\circ} \mathrm{C}$ at a constant metabolic rate.

Another building factor that may negatively impact thermal sensation in the stalls is the ceiling height. According to Baêta and Souza (2010), livestock facilities should be at 
least $2.80 \mathrm{~m}$ high to facilitate ventilation and reduce the incident radiation from the roof.

When comparing the thermal conductivity of roofing materials exposed to direct solar radiation, Baêta and Souza (2010) reported that metals have a thermal conductivity on the order of $47 \mathrm{~W} / \mathrm{m} .{ }^{\circ} \mathrm{C}$, while in masonry buildings, it reaches $1.47 \mathrm{~W} / \mathrm{m} .{ }^{\circ} \mathrm{C}$. Therefore, although clay-roofed stalls have a lower ceiling height, they provide greater thermal comfort to horses. When studying the efficiency of roof tiles made of several kinds of materials using a wooden-gable roof framing of $2.00 \times 1.00 \times 1.75 \mathrm{~m}$ on thermal comfort indexes from January to February, Sevegnani et al (1994) concluded that clay tiles provided higher thermal comfort, followed by tiles made of aluminum, thermal insulation tiles, asbestos cement, zinc, and fiberglass.

Although the feed supplied to horses had an identical chemical composition, the shortest time spent eating roughage and the number of bites observed in horses kept in clay-roofed stalls may be associated with the thermal comfort provided by this roofing material. The thermal environment strongly influences animal performance, especially regarding feeding time in uncomfortable environments; thus, it affects heat transfer mechanisms and the heat balance between an animal and its environment (Perissinoto and Moura 2007). It can be justified by the values of WBGT, relative humidity, and air temperature in clayroofed stalls, indicating higher thermal comfort.

Table 5 Total feeding time (concentrate and roughage intake) and time spent in other activities by horses kept in different types of stalls.

\begin{tabular}{lcc}
\hline Behavioral variables & Clay-roofed stalls & Zinc-roofed stalls \\
\hline Total feeding time (hours) & 7.22 & 8.32 \\
\hline Concentrate (\%) & 5.61 & 5.33 \\
Roughage (\%) & 94.39 & 94.33 \\
\hline Time spent in other activities (hours) & 16.78 & 15.68 \\
\hline Walking (\%) & 1.25 & 1.59 \\
Resting (\%) & 72.7 & 72.4 \\
Lying down (\%) & 3.3 & 2.8 \\
Sleeping (\%) & 12.8 & 13.4 \\
Cribbing (\%) & 0.2 & 2.2 \\
Restless (\%) & 1.7 & 2.9 \\
Training (\%) & 5.9 & 1.6 \\
Licking the feed trough (\%) & 2.3 & 3.2 \\
Wood-chewing (\%) & 0.00 & 0.08 \\
\hline
\end{tabular}

According to the NRC (2007), the amount of water ingested was lower than that required for horses, which may impair the animal's thermal regulation. For McDonnell et al (2002), stabled horses consuming water in buckets, possibly due to physical and sensory stimulus associated with consumption, may show an increase of up to $30 \%$ in water intake compared to horses receiving water through automatic water troughs. It could explain, among other previously mentioned aspects, a possible increase in water intake per $\mathrm{kg}$ of dry matter ingested compared to the other authors. Horses should drink water every 30-40 minutes; therefore, animals should be trained to drink water when it is offered (Harris 2009).

According to McGreevy et al (1995), horses kept in stalls that allow little contact with the outside environment tend to exhibit a higher percentage of abnormal behaviors than horses kept in stalls with extensive visual contact with other animals and humans. Horses spent most of the time standing in front of the stall, observing the outside. It indicates great curiosity and the need for contact with other animals and humans, possibly decreasing boredom. The same behavior was observed in the study conducted by Rezende et al (2006b) with two breeds of stabled horses. Overall, horses spend relatively little time lying down even when free, particularly less time when they are stabled.

The leading causes of these behavioral disorders were probably boredom (total resting time) compared to the natural habitat since there were no dietary deficiencies or a shortage of roughage supply (Krzak et al 1991; McCall 1993). In the same way, Rezende et al (2006) found that these disorders tend to be more frequent due to longer resting time in stabled animals, reaching 0.17 and $0.08 \%$ in Breton and Percheron horses, respectively.

\section{Conclusions}

The time spent eating roughage and bite rate were highest in horses kept in zinc-roofed stalls with high ceiling height. The other behavioral factors were not altered by the roofing type in conditions of the semiarid region of Minas Gerais. 
The feeding frequency should be increased to avoid a long resting time. Further studies during other seasons are necessary to verify the effect of roofing types suitable to the semiarid region.

\section{Acknowledgments}

The authors thank the Foundation for Research Support of the State of Minas Gerais (FAPEMIG), the National Council for Scientific and Technological Development (CNPq).

\section{Conflict of Interest}

The authors declare that they have no conflict of interest.

\section{Funding}

This study was financed in part by the Coordenação de Aperfeiçoamento de Pessoal de Nível Superior - Brasil (CAPES) - Finance Code 001.

\section{References}

Antunes FZ (1994) Caracterização climática. Informe Agropecuário 17:15-19.

Baêta FC, Souza CF (2010) Ambiência em edificações rurais: conforto animal. 2.ed. EDUFV,Viçosa, MG.

Brandi RA, Furtado CE (2009) Importância nutricional e metabólica da fibra na dieta de equinos p. 246-258. In: Anais da 46a Reunião Anual da Sociedade Brasileira de Zootecnia, Sociedade Brasileira de Zootecnia, Maringá.

Buffington DE, Collazo - Arocho A, Canton GH, Pitt D (1981) Black globe humidity index (BGHI) as a comfort equation for dairy cows. Transactions American Society Agricultural Engineers 4:711-714.

Canal JR A (2015) Influência do tempo de estabulação no comportamento de equinos da raça crioula. Unoesc \& Ciência 6:203-210.

Detmann E, Souza MA, Valadares Filho SC, Queiroz AC, Berchielli TT, Saliba EOS, Cabral LS, Pina DS, Ladeira MM, Azevedo JAG (2012) Métodos para análise de alimentos. UFV, Viçosa, MG.

Harris PA (2009) Feeding management of elite endurance horses. The Veterinary Clinics of North America: Equine Practice 25:137-153.
Hodgson J (1985) Ingestive behaviour. p.113-138. In: Herbage intake handbook . Leaver JD ed. The British Grassland Society.

INMET- Instituto Nacional De Meteorologia (1992) Normas climatológicas aparentes (1961-1990). INMET, Brasília.

McCall C. Solving behavior problems in horses. Equine Practive 15:30-31.

McDonnell SM (2002) Behaviour of Horses. p.119-130. In: The Ethology of Domestic Animals. Per Jensen. CABI Publishing, UK.

McGreevy PD, Cripps PJ, French NP, Green LE, Nicol CJ (1995) Management factors associated with stereotypic and redirected behavior in Thoroughbred horse. Equine Veterinary Journal 27:86-91.

Mills DS (2005) Repetitive movement problems in the horse. p.212-227. In: The domestic horse: the evolution, development and management of it's behaviour. Cambridge University Press, Cambridge.

Morgan K. (1996) Short-term thermoregulatory responses of horses to brief changes in ambient temperature. Swedish University of Agricultural Sciences. Departament of Agricultural Engineering, Uppsala, 09-51.

NRC - National Research Council. Nutrient Requirements of Horses (2007) National Academy of Sciences, Washington, DC. 341p.

Perissinoto M, Moura DJ (2007) Determinação do conforto térmico de vacas leiteiras utilizando a mineração de dados. Revista Brasileira de Engenharia de Biossistemas, 1:117-126.

Rezende MJM, Mcmnus C, Paludo GR, Martins RD, Oliveira LPG, Fuck BH, Louvandini H (2006b) Comportamento de equinos das raças Bretã e Percheron estabulados. Ciência Animal Brasileira 7:17-25.

Rezende MJM, McManus C, Martins RD, Oliveira LPG, Garcia JAS, Louvandini $\mathrm{H}$ (2006a) Comportamento de equinos estabulados do exército brasileiro em Brasília. Ciência Animal Brasileira 7:327- 337.

Santos EM, Zanine AM, Parente HN, Ferreira DJ, Almeida FQ, Cecon PR (2006) Comportamento ingestivo de eqüinos em pastagens de grama batatais (Paspalum notatum) e braquiarinha (Brachiaria decumbens) na região centro-oeste do Brasil. Ciência Rural 36:565-1569.

Sevegnani KB, Ghelfi Filho H, DA Silva IJO (1994) Comparação de vários materiais de cobertura através de índices de conforto térmico. Scientia Agricola 51:01-07.

Thorne JB, Goodwin D, Kennedy MJ, Davidson HPB, Harris P (2005) Foraging enrichment for stabled horses: practicality and its effect on behaviour. Applied Animal Behavior Science 94:149-164. 